\title{
Central Forest Library Acquisition List No. 62, May 2014
}

Arora, P. N., Arora, S. and Arora, S. 2012. Comprehensive Statistical Methods. S. Chand and Company Pvt. Ltd., New Delhi, 202p.

Aitken, B. 2004. Touching Upon the Himalaya: Excursions and Enquiries. Indus Publishing Company, New Delhi, 168p.

Baral, S. R. and Kurmi, P.P. 2006. ACompendium of Medicinal Plants in Nepal. Mass Printing Press, Kathmandu, 534p.

Bentley, L. and Brad, S. 2003. Intellectual Property Law. Oxford University Press, New Delhi, 1051p.

Bhuyan, K. C. 2010. Probability Distribution Theory and Statistical Inference. New Central Book Agency, London, 946p.

Bhattacharyya, B. and Banerjee, R. 2010. Environmental Biotechnology. Oxford University Press, New Delhi, 338p.

Connolly, A. 2010. 101 Ways to Score Higher on Your GMAT: What you need to know the Graduate Management Admission Test Explained Simply. JAICO Publishing House, Lucknow, 288p.

Christopher, D. 2010. Successful Project in Visual Basic. BPB Publications, New Delhi, 248p.

Chakraborty, P. 2006. Computer Architecture and Organization: A Journey Through Evolution. JAICO Publishing House, Kolkata, $105 p$.

Cheremisinoff, N. P. 2001. Biotechnology for Waste and Wastewater Treatment. PrenticeHall of India Private Limited, New Delhi, 231p.

Corbett, J. 1999. The Man-eating Leopard of Rudraprayag. Oxford University Press, Calcutta, 191p.

Challa, S. N. M. 2002. Water Resources Engineering: Principles and Practice. New Age international Publishers, India, 306p.

Chaudhari, N. C. 2008. The Heart of India. JAICO Publishing House, New Delhi, 350p.
Chand, D. 2002. Essays on Development of Nepal. Chandani Publication Pvt. Ltd., Kathmandu, 149p.

Desai, A. 1989. Environment and Entrepreneur. S. B. Nangia, New Delhi, 247p.

Dubash, N. K. 2012. Handbook of Climate Change and India: Development, Politics and Governance. Oxford University Press, New Delhi, 400p.

Datta, S. 2010. Amazing Adaptations. National Book Trust, New Delhi, 188p.

Dubash, N. K. 2012. Handbook of Climate Change and India: Development, Politics and Governance. Oxford University Press, New Delhi, 400p.

Evans, P. 2006. Information Technology: For Everybody-Volume 1. BPB Publications, New Delhi, 232p.

Gupta, M. P. 2009. Crisis Management. Essential Books, New Delhi, 286p.

George, K. J. 2003. Operating system: Concepts and Principles. SHROFF publishers and distributors, Navi Mumbai. 363p.

Hill, N. 2012. The Master-Key to Riches. Maanu graphics, New Delhi, 231p.

Hammett, M. 2006. Dictionary of International Trade Finance Terms. Biztantra, New Delhi, 266p.

Hay, P. 2002. A Companion to Environmental Thought. Rawat Publications, New Delhi, 400p.

Heathcote, P. M. 2008. Computing. BPB Publications, New Delhi, 208p.

Heathcote, P. M. and Richards, R. P. 2001. Information Technology: For EverybodyVolume 2. BPB Publications, New Delhi, 218p.

Kala, C. P. and Silori, C. S. 2013. Biodiversity Communities and Climate Change. Teri The Energy and Resources Institute, Calcutta, 330p.

Sheth, R. P. 2008. The Sun. National book trust, India, $124 \mathrm{p}$. 
Lakshmikanthamma, S. 1997. Sustainability of Dryland Agriculture in India (A case Study of Watershed Development Approach). MD Publication Pvt. Ltd., New Delhi, 339p.

Marcum, B. D. and George, G. 2006. Digital Library Development. Libraries unlimited, London, 269p.

Mishra, S. K. 1994. Sustainable Growth of Agriculture in India. M D Publications Pvt. Ltd., New Delhi, 123p.

Padma, T. and Rao, K. P. C. 2010. The Principles of Environmental Law. ALT Publication, Hyderabad. 335p.

Puri, B. 2009. New Illustrated Computer Course. A.I.T.B.S. Publishers, India. 439p.

Rashid, S. M., Ishtiaq, M., Hashia, H. and Rahman, A. 2008. Environment, Resources and Sustainable Development. Rawat Publication, New Delhi, 430p.

Rabb K. and Shamshur, M. 2012. UGC-NET/ SET: Computer Science and Applications. Ramesh Publishing House, New Delhi, 708p.

Rao, M. S. 1995. Encyclopedic Dictionary of Geography Vol. 2. Anmol publications Pvt. Ltd., New Delhi, 611p.

Sinha, J. and Bhardwaj, A. 2011. Environmental Science. Galgotia Publication Pvt, Ltd., New Delhi, 270p.

Saxena, G. 1990. The Forest Crisis. Natraj Publishers, Dehra Dun, 182p.

Saxena, N. C. 1995. Forests, People and Profit: New Equations for Sustainability. Natraj Publishers, Dehra Dun, 276p.

Shephard, D. R. 2001. Introduction to Computers and Technology. Crest Publishing House, New Delhi, 344p.

Sidhu, K. S. 2013. Methodology of Research in Education. Sterling Publishers Private Limited, New Delhi, 308p

Samual, C. K. 2007. Poverty, Social Capital and Natural Resource Management. Rawat Publications, New Delhi, 260p.

Williams, N. 2005. Fury of Natural Disasters Moving Stories of Struggle and Survival.
Epitome Books, New Delhi, 234p.

Yadav, R. P. 2009. Statistical Methods. Asmita Books and Publishers Pvt. Ltd., Kathmandu, $427 \mathrm{p}$.

\section{[Datice}

The Central Forest Library hereby requests all researchers, academicians and students to send one copy of their thesis and research papers related to forestry, wildlife, botany, soil conservation, socioeconomic studies, medicinal plants, environment and biodiversity to this library.

\section{Central Forest Library}

Department of Forest Research and Survey,

$$
\text { P.O. Box : 3339, Kathmandu, Nepal }
$$

E-mail: info@dfrs.gov.np

Tel. No. 4220482/4269491 